\title{
Three Pillars Partnership in The Tourism Destinations Management in Order to Actualize Good Tourism Governance (Study on a Rafting Tour in Probolinggo Regency)
}

\author{
Lely Indah Mindarti",Muhammad Fahmi Lazuardi \\ Department of Public Administration, Faculty of Administrative Science, Universitas Brawijaya,
} Malang, Indonesia

\begin{abstract}
Three pillars partnership in the tourism destinations management in orderto actualize Good Tourism Governance has been studied with a special case on a rafting tour in Probolinggo Regency. In tourism development, the synergy of the three pillars (state, private companies, and society)is necessary. Probolinggo Regency Government in the management of the rafting tour services conducts a partnership with private sectors and society. According to the objectives of the study that have been set, the type of this research is descriptive research with a qualitative approach. In data collection, the data were collected from observations, interviews, and documents of agreement. The method of data analysis used the analysis of Miles and Huberman. The result of this research showed that Probolinggo Regency Government has conducted a partnership with the private companies and the society in managing the tourism destinations. In this case, the three pillars have their responsibility to manage the rafting tour. However, the partnership of those three pillars has to be conducted continuously to actualize Good Tourism Governance.
\end{abstract}

Keywords: Good tourism governance, Partnership, Three pillars, Tourism

\section{INTRODUCTION}

Indonesia as a developing country should emphasize that development is a significant mechanism to increase the society life quality. One of the important development sectors to be expanded is Tourism. Indonesia as an archipelago country which has natural wealth makes Indonesia as a tourism destination that has ahuge contribution for increasing economy aspect. It can be shown from the Ministry of Tourism and Creative Economy datainformed that the tourism sector contributes foreign exchange of US\$ 10.69 billion, equivalent to Rp.136 trillion [1]. Thus it proved that the tourism sector is a potential sector which is enthused by all levels not only local but also international tourists.

Indonesia is as a country which has natural wealth and becomes the area for tourism development. Probolinggo Regency is one of the regencies in East Java has tourism wealth. One of the famous tourism in Probolinggo is rafting. The rafting tourism is located at Pekalen River that is originated from springs of Mount Argopuro [2].

However, Probolinggo still needs to increase the service management in terms of tourism destination so that it can give a positive effect on

Correspondence address Lely Indah Mindarti

Email : lelyfia@ub.ac.id

Address : Department of Public Administration, Faculty of Administrative Science, Universitas Brawijaya the tourist inflow in Probolinggo and on the economy increase of the surrounding society. Therefore, with the existence of tourism objects in Probolinggo, society can be more empowered.

Consequently, upon all efforts of the tourism destination service improvement, Probolinggo needs good cooperation among the three pillars of Governance. They are State, Private Companies, and Society to reach their common goal of a good tourism destination service.

The objective of this study was to analyze the performance and the partnership between the three pillars of Governance in Probolinggo Regency. In the case of Probolinggo Regency of Tourism and Culture Department regarding the private parties and the societies about the management of tourism destination service to actualize good tourism government.

\section{Good Governance}

Public administration is a process where the resources and public personnel are organized and coordinated to formulate, implement, and manage public decision and policy [3]. According to the World Conference on Governance, UNDP in module 1. C, D, E on Education and Leadership Training level II of State Administrative Agency (LAN) Study Paradigm (SPIMNAS) in Education and Training Centre in Leadership sector, Jakarta, 2012, Good Governance is a process of a good government system management, involving stakeholders toward various economic, social, and politic activities and the utilization of various 
natural, financial, and human resources for society interest that is conducted based on the principles: justice, equalization, equity, efficiency, transparency, and accountability [4].

Eight Good Governance Principles according to The United Nations Development Program's (UNDP) are as follows: Participation, Rule of Law, Transparency, Responsiveness, Consensus Orientation, Equity, Efficiency and Effectiveness, and Accountability. Sjamsuddin [5] explained the elements of Governance stakeholder consist of three sectors, as follows.

State

The definition of the state generally covers all political agency and public sectors. The state or government's role and responsibility involve public service performance, power enforcement to rule/government duty, and creating a conducive situation to reach the development goals either in local, national, or international level.

\section{Private sectors}

Private sectors, in this case, involve some companies in market system interaction, such as manufacture, trading, banking, cooperatives, and also the other informal sectors. The role of private sectors is very important for the government and development since their duty is as an opportunity to fix productivity, employment/job provider, income source, public investment, business expansion and, economic growth.

\section{Civil Society}

Civil society is an individual or a group of society who interacts and socializes socially, politically, and economically. Civil society does not only do check and balances toward the government authority and the private sectors but also gives a contribution to strengthen the other elements.

\section{Good Tourism Governance}

Good Tourism Governance is a coordination and synchronization program among the stakeholders and the actively synergic involvement (integrated and mutually reinforcing) among the government, private sectors/tourism industry and the related surrounding society [6]. In Good Tourism Governance, public sector needs a change in the way of thinking or acting, especially leaving the old centralistic government paradigm (Constitution No. 32/2004). In Tourism
Governance, there are some performance principles.

\section{Participation of Related Society}

In this case, society should be involved in deciding the vision, the mission, and the purpose of tourism development.

\section{Involvement of All Stakeholders}

The stakeholders should involve actively and productively in tourism development. The stakeholders here include the Non-Governmental Organization (LSM), volunteers, Local Government, Tourism Industry Association, Business Association, and the other related parties.

\section{Partnership of Local Ownership}

Tourism development should be able to give a contribution to the society that is the local people who live in the surrounding area.

\section{Continuously Resources Utilization}

Continuously Utilization means that tourism development should avoid the use of irreversible resources excessively.

\section{Society Aspiration Accommodation}

Society suggestion and aspiration should be able to be accommodated in the tourism activities program to generate harmonic relationship among the tourists, the business people, and the surrounding society.

\section{Environment Support Capacity}

Environment support society should be adjusted in developing various tourism facilities and activities.

\section{Monitoring and Evaluation Program}

Program of monitoring and evaluation in tourism development covers from guidelines creation, tourism activities effect evaluation, indicators development in measuring tourism effect, up to monitoring and evaluation.

\section{Environment Accountability}

Tourism development program strategy should pay attention to the job opportunity, the income and the health of the surrounding society, which are listed in the tourism development policy, program, and strategy.

\section{Training for the Related Society}

Society needs to be empowered. The society empowerment through education and training programs in order to give knowledge and skill for the society and to improve their business skill vocationally and professionally. 


\section{Promotion and Advocacy of Local Culture Value}

Good tourism development and management need promotion and advocacy of its local culture value. It means maintaining and conserving the cultural identity of the local society very well for visitors and tourist's satisfaction.

\section{Public Services}

Public service is an endeavor that is done by a community or an individual or a bureaucracy to give help to society in reaching a certain goal [7]. Public service principles [8] consist of:

1. Transparency; Means that openness and accessibility for all parties.

2. Accountability; Can be accountable based on the applicable provision.

3. Conditional; Adjust with the principal condition toward efficiency and effectiveness.

4. Participative; Support the society role in public service.

5. Rights Safety; There is no discrimination

6. Balance of Rights and Duties; Rights and duties fulfillment between the service provider and the service receiver, in this term, they are the government and the society.

\section{Partnership}

Public-Private Partnership is a work unit of government service provider or government business unit, such as Indonesian State-Owned Enterprise (BUMN) or Regional Owned Enterprise (BUMD) which cooperate with the private sectors and the third sector [9]. Public-Private Partnership is a cooperation of half government authority allocation toward the private sectors to conduct half or whole development activities and infrastructure operation [10].

\section{Tourism}

Tourism is various tour activities which are supported by various facilities and services provided by society, entrepreneurs, government, and local government [11]. Tourists in tourism can be divided into five classifications [12]:

1. Domestic Tourism is tourism caused by people who stay and live in that country.

2. Inbound Tourism is tourism as the arrival of people who are not the natives of that country.

3. Outbound Tourism is tourism as a visit of natives of one country to another country.
4. Internal Tourism is a combination of Domestic Tourism and Outbound Tourism

5. International Tourism is a combination of Inbound Tourism and Outbound Tourism.

There are three main elements of tourism [13].

1. Tourist is an important actor in tourism activities

2. Geography Elements

The tourist original area; is an area where the tourists are and do daily routines. From the tourist original area, they can access information related to the tourism destination they want.

Transit area; is an area which is made as an area where tourists can stop temporarily and continue their journey again.

Tourism destination area; is the targeted area by the tourists and should be managed well so that area can provide entertainment for the tourist.

3. Tourism Industry is an element which offers service, attractiveness, and excursion. Tourism industry consists of travel agencies which provide tourist accommodation.

Indonesian Constitution No. 10 of 2009, article 5 about tourism, explained the principles of tourism performance are:

- Upholding the religious norms and cultural values as an embodiment from the life concept in the balance of the relationship between human beings and God, the relationship among the human beings, and the relationship between human beings and the environment.

- Upholding human rights, cultural diversities, and local wisdom.

- Giving benefits for society welfare, justice, equality, and proportionality.

- Maintaining the nature conservation and environment.

- Empowering the local society.

- Guaranteeing the coherence among sectors, among regions, between the central government and local government which becomes one systemic unity in regional autonomy framework, and the coherence among the stakeholders.

- Obeying tourism ethic codes and International agreement in the tourism field.

- Strengthen the integrity of the Republic of Indonesian (NKRI). 


\section{Tourism Development Partnership}

According to Medium-Term Regional Development Plan of Probolinggo Regency period 2013-2018, tourism partnership is listed in point $C$ in the program of Regional Work Units (SKPD) Culture and Tourism Department, on the other hand, the terms of tourism development is based on point $\mathrm{C}$ that is listed in Medium-Term Regional Development Plan program.

\section{MATERIAL AND METHOD}

In this research, the researcher used a descriptive type of research with a qualitative approach [14]. The focuses of this research are (1) Tourism destination in Probolinggo Regency and (2) Partnership form among the three pillars of Governance in the rafting tour service management as an effort to actualize Good Tourism Governance.

The data source of this research was obtained through primary and secondary data.Data collection was obtained from the results of observations, interviews, and document of agreement. Data collectionwas carried out for four monthswith detailed observations; interviews with five informants (head of the department, marketing staff, tourists) also document of agreement.

Next, in data analysis, the researcher used data analysis steps based on Miles and Huberman in Sugiyono they are: data reduction, data display, and conclusion drawing/verification [15].

\section{RESULT AND DISCUSSION}

\section{Tourism Destination in Probolinggo Regency}

Probolinggo is a region which has excellent natural resources. It makes Probolinggo Regency as a region which has national and international level tourism potency [16]. Probolinggo also has the other tourism destination in other sectors, such as beaches, lakes, and water sport, such as rafting which pumps adrenaline. The work units program in Medium-Term Regional Development Plan (RPJMD) of Probolinggo Regency listed in some points:

1. Tourism Marketing Development Program

2. Tourism Object Development Program

3. Tourism Service and Partnership Program

According to the Head of Tourism Division in Culture and Tourism Department of Probolinggo Regency, there are hundreds of tourism objects in Probolinggo Regency. However, they need to be improved and developed together by the three pillars of governance. Tourism destinations which are managed by Probolinggo Regency Government are:

1. Mount Bromo

2. Madakaripura

3. Bentar Beach

4. Rafting

5. Ronggojalu Water Tourism

6. Ranu Segaran

7. Wisma Ucik (lodging house)

The tourism destinations above are managed by Probolinggo Regency Government through Culture and Tourism Department. It means that the income goes to Local Own-source Revenue (PAD). However, among all seven tourism destinations mentioned, there is only one that is managed by the government, private sectors, and society, it is Rafting. For the other five tourism destinations, they are managed fully by Probolinggo Regency Government. On the other hand, Mount Bromo is managed together with Bromo Tengger Semeru National Park (TNBTS) [17].

\section{Rafting Tour in Probolinggo Regency}

According to Head of Tourism Division of Culture and Tourism Department of Probolinggo Regency, rafting in Probolinggo Regency is located in Ranu Gedang Village, Tiris District, Probolinggo. It is located at Pekalen River that is originated from springs of Mount Argopuro and Mount Lamongan [2]. The width of the river is about 5-20 meters and the depth is about 1-3 meters. The rafting distance of the river is more or less than $12 \mathrm{~km}$ that takes three and a half hours with the rafting difficulty level is on grade II and grade III+.

The rafting tourism of Probolinggo Regency Government via Culture and Tourism Department conducts a partnership with the private sectors and society. The private sectors or the operators of the rafting that is trusted to conduct the partnership are:

1. PT. Condong Pandawa Nusantara (NOARS)

2. PT. Songa Alam Lestari

3. PT. Regulo Lintas Nusantara

Next, the society party consists of Tourism Awareness Community and Tourism Care Citizens who take a part in cooperating, maintaining, and conserving the beauty of tourism objects and giving tourism education toward the local and international tourists [18]. 
Partnership Form among the Three Pillars of Governance in Managing the Rafting Tourism Object in Probolinggo Regency

The partnership form among the three pillars of Governance in managing the rafting tourism object in Probolinggo Regency has been set in the cooperation agreement between Probolinggo Regency Government as the first party and the three operators of Rafting service provider by involving the society role as stated in the agreement number 181/87/428.12/212 (PT. Condong Pandawa Nusantara), number 181/88/426.12/212 (PT. Regulo Lintas Nusantara), and number 181/89/426.12/212 (PT. Songa Alam Lestari).

Probolinggo Regency Government in Managing and Developing the Rafting Tourism Service

Probolinggo Regency Government as the first party has several responsibilities.

1. Providing the management access of rafting attractiveness with some routes:

- Pekalen Atas River including the river stream in Ranu Gedang Village, Jangkang Village, Pesawahan Village, Racek Village in Tiris District

- Pekalen Bawah River including the river stream in Pesaahan Village, Racek Village in Tiris District, Brabe Village in Maron District, and Condong Village in Gading District.

2. Giving license and infrastructure facilities, such as path, bridge, and the other public facilities in order to accelerate the management of rafting attractiveness [18].

3. Giving support in the form of promotion of rafting attractiveness in order to increase the number of tourist visits in Probolinggo Regency [19].

The Three Operators of Rafting Service Provider

In this case are PT. Condong Pandawa Nusantara (NOARS), PT. Songa Alam Lestari, and PT. Regulo Lintas Nusantara. In managing and developing the rafting service, the three operators as the second party have some responsibilities, they are:

1. Paying contribution for Local Own-source Revenue (PAD) toward the first party, in this case, is Probolinggo Regency Government.

2. Ensuring the first party to stay maintaining the river characteristics and will not change or build the other building facilities at the river and will maintain the aesthetics in the river environment.
3. Making reports periodically toward Probolinggo Regency Government through Culture and Tourism Department about the tourism activities and visit flow.

4. Empowering the potency of the society around the rafting location in every rafting activity in line with the capacity needed by the second party.

5. Guaranteeing the visitors safety and comfort at the rafting location.

6. Providing rafting facilities and infrastructure, safety tools, and insuring every rafting participant [18].

7. Obeying the rules related to the flow/route that has been set.

\section{Society}

The society role in managing and developing rafting tourism service is very important [19]. It is known that society consists of various components; they are Tourism Awareness Community, Tourism Care Citizens, and the local society. The roles of the society components to support rafting tourism service are:

1. Participating in maintaining the environment and the rafting site.

2. In the document agreement, it is stated to empower the potency of the society around the rafting site in every activity.

3. Maintaining security around the site and becoming the direction indicator for the tourists.

4. Taking a part in monitoring the implementation of the rafting tourism service.

From the discussion above, the three pillars have strategic roles in managing rafting destinations. Government, private sectors, and society have a sustainable relationship (Fig. 1). In this case, the government is as the authorized party in monitoring the rafting tourism activities. On the other hand, private sectors, in this case, are the three operators as the rafting service provider. It also involves society as a form of society empowerment [19].

The partnership between government, private sectors, and society should be continuous. It means that it does not stop and keeps trying to improve the tourism service especially the rafting, because with the continuous tourism service management, the related parties, in this case, are government, private sectors, and society can actualize Good Tourism Governance [19]. 


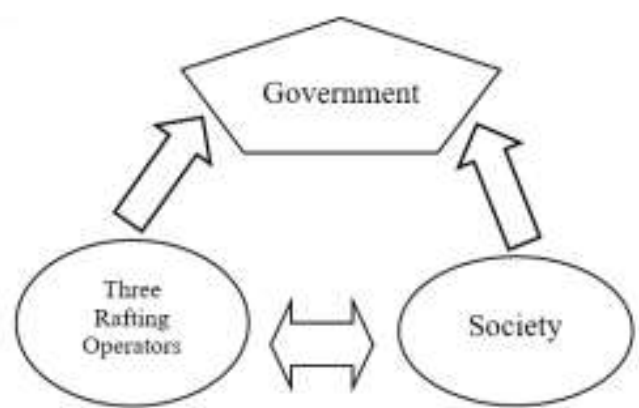

Figure 1. The Chart of Three Pillars Partnership

\section{CONCLUSIONS}

The three pillars partnership in managing the rafting tourism service in Probolinggo Regency has worked well. It can be proven by the roles and the responsibilities of each three pillars; they are government, private sectors, and society. In this case, government is as the party that provides tourism access to support the rafting tourism, provides license facilities, and monitors tourism service activities that are conducted by the private parties. The private sectors play role as tourism service provider, including the facilities and the infrastructure to support the rafting tourism service. They also take a part in empowering the local society, and also the participation of the other society components. All roles and responsibilities which are conducted among the three pillars need to be continued in order to actualize Good Tourism Governance.

\section{REFERENCES}

[1] Ayu, K.2017. Kota-kota besar sebagai pemilik pariwisata Indonesia.Available at https://www.kompasiana.com/kartikaayusr /5901d7116ea8345f078b4567/kotakotabesar-sebagai-pemilik-pariwisata-indonesia.

[2] Aulia, A. N. and L. Hakim. 2017. Pengembangan potensi ekowisata sungai Pekalen Atas, Desa Ranu Gedang, Kecamatan Tiris, Kabupaten Probolinggo. Jurnal Wilayah dan Lingkungan 5 (3), 156167.

[3] Chandler, R. C. and J. C. Plano. 1988. The public administration dictionary. John Wiley \& Sons.

[4] World Conference on Governance. 2012. UNDP in module 1. C, D, E on Education and Leadership Training level II of State Administrative Agency (LAN) Study Paradigm (SPIMNAS) in Education and Training Centre in Leadership Sector. Jakarta.
[5] Sjamsuddin, S. 2006 Kepemerintahan dan kemitraan. CV. Sofa Mandiri Publisher. Malang.

[6] Sunaryo, B. 2013. Kebijakan pembangunan destinasi pariwisata. Gava Media Publisher. Yogyakarta.

[7] Moenir, A.S.1995. Manajemen pelayanan umum di Indonesia. Bumi Aksara Publisher. Jakarta.

[8] Sinambela, L. P. 2008. Reformasi pelayanan publik. Bumi Aksara Publisher. Jakarta.

[9] Mahmudi. 2007. Kemitraan pemerintah daerah dan efektivitas pelayanan publik. Sinergi 9(1), 55.

[10] Irianti, A. F. 2011. Kemitraan pemerintah dan swasta dalam pengelolaan pariwisata. Bachelor Thesis. University of Brawijaya. Malang.

[11] Republic of Indonesia Constitution. 2009. Number 10 about tourism. Republic of Indonesia, Jakarta.

[12] Smith, S. L.S. 1998. Tourism analysis: a handbook. Longman Group. Harlow, England.

[13] Cooper, C., J. Fletcher, D. Gilbert, A. Fyall, S. Wanhill. 1998. Tourism principles and practice. Longman. England.

[14] Moleong, L. J. 1989. Metodologi penelitian kualitatif. Remadja Karya Publisher. Bandung.

[15] Sugiyono. 2012. Metode penelitian kuantitatif kualitatif dan R\&B. Alfabeta Publisher. Bandung.

[16] Bahiyah, C. W.H.Riyanto, and S. Sudarti. 2018. Strategi pengembangan potensi pariwisata di Pantai Duta Kabupaten Probolinggo. Jurnal IImu Ekonomi 2(1), 95103.

[17] Wira, N.N.2018. Jakpost explores Mount Bromo. Available at: https://www.thejakartapost.com/travel/20 18/07/28/jakpost-explores-mountbromo.html.

[18] Rachmawati, Y. 2014. Wisata arung jeram Pekalen, Probolinggo. Avaliable at: https://www.merdeka.com/gaya/wisataarung-jeram-pekalen-probolinggo.html.

[19] Sunarta, N. and N. S. Arida. 2017. Pariwisata berkelanjutan. Cakra Press. Bali. 